University of Wollongong

Research Online

Faculty of Health and Behavioural Sciences -

Papers (Archive)

Faculty of Science, Medicine and Health

$1-1-2012$

\title{
Association between food marketing exposure and adolescents' food choices and eating behaviors
}

\author{
Maree Scully \\ Cancer Council, VIC \\ Melanie Wakefield \\ Cancer Council Victoria \\ Philippa Niven \\ Cancer Council, VIC \\ Kathy Chapman \\ Cancer Council, NSW \\ David Crawford \\ Deakin University
}

See next page for additional authors

Follow this and additional works at: https://ro.uow.edu.au/hbspapers

Part of the Arts and Humanities Commons, Life Sciences Commons, Medicine and Health Sciences Commons, and the Social and Behavioral Sciences Commons

\section{Recommended Citation}

Scully, Maree; Wakefield, Melanie; Niven, Philippa; Chapman, Kathy; Crawford, David; Pratt, lain S.; Baur, Louise A.; Flood, Victoria; and Morley, Belinda: Association between food marketing exposure and adolescents' food choices and eating behaviors 2012, 1-5.

https://ro.uow.edu.au/hbspapers/3042

Research Online is the open access institutional repository for the University of Wollongong. For further information contact the UOW Library: research-pubs@uow.edu.au 


\title{
Association between food marketing exposure and adolescents' food choices and eating behaviors
}

\author{
Abstract \\ The present study examined associations between food marketing exposure and adolescents' food \\ choices and reported consumption of energy-dense and nutrient-poor (EDNP) foods. A cross-sectional \\ survey of 12,188 Australian secondary students aged 12-17 years was conducted, using a web-based \\ self-report questionnaire. Measures included students' level of exposure to commercial television and \\ non-broadcast types of food marketing, whether they had tried a new product or requested a product they \\ had seen advertised, and their reported consumption of fast food, sugary drinks and sweet and salty \\ snacks. Results indicated greater exposure to commercial television, print/transport/school food \\ marketing and digital food marketing were all independently associated with students' food choices. High \\ commercial television viewers ( $>2 \mathrm{~h}$ /day) were more likely to report higher consumption of EDNP foods \\ (ORs ranged from 1.31 for fast food to 1.91 for sweet snacks). Some associations between digital food \\ marketing exposure and students' eating behaviors were found; however, print/transport/school food \\ marketing was only related to sweet snack consumption. These study results suggest that cumulative \\ exposure to television food advertising and other food marketing sources are positively linked to \\ adolescents' food choices and eating behaviors. Policy changes to restrict food marketing to young \\ people should include both television and non-broadcast media.
}

\section{Keywords}

choices, eating, association, behaviors, between, food, marketing, exposure, adolescents

\section{Disciplines}

Arts and Humanities | Life Sciences | Medicine and Health Sciences | Social and Behavioral Sciences

\section{Publication Details}

Scully, M., Wakefield, M., Niven, P., Chapman, K., Crawford, D., Pratt, I. S., Baur, L. A., Flood, V. \& Morley, B. 2012, 'Association between food marketing exposure and adolescents' food choices and eating behaviors', Appetite, vol. 58, no. 1, pp. 1-5.

\section{Authors}

Maree Scully, Melanie Wakefield, Philippa Niven, Kathy Chapman, David Crawford, lain S. Pratt, Louise A. Baur, Victoria Flood, and Belinda Morley 


\title{
Association between food marketing exposure and adolescents' food choices and eating behaviours
}

Maree Scully ${ }^{\mathrm{a}}$ Melanie Wakefield ${ }^{\mathrm{a}}$, Philippa Niven ${ }^{\mathrm{a}}$, Kathy Chapman ${ }^{\mathrm{b}}$, David Crawford ${ }^{\mathrm{c}}$, Iain S. Pratt ${ }^{\mathrm{d}, \mathrm{e}}$, Louise A. Baur ${ }^{\mathrm{f}}$, Victoria Flood ${ }^{\mathrm{g}}$, Belinda Morley ${ }^{\mathrm{a}}$, for the NaSSDA Study Team 1

Keywords: Food marketing; Adolescents; Behavior; Cross-sectional study

\begin{abstract}
Objectives: The present study examined associations between food marketing exposure and adolescents' food choices and reported consumption of energy-dense and nutrient-poor (EDNP) foods. A cross-sectional survey of 12,188 Australian secondary students aged 12-17 years was conducted, using a web-based self-report questionnaire. Measures included students' level of exposure to commercial television and non-broadcast types of food marketing, whether they had tried a new product or requested a product they had seen advertised, and their reported consumption of fast food, sugary drinks and sweet and salty snacks. Results indicated greater exposure to commercial television, print/transport/school food marketing and digital food marketing were all independently associated with students' food choices. High commercial television viewers ( $>2 \mathrm{~h} /$ day) were more likely to report higher consumption of EDNP foods (ORs ranged from 1.31 for fast food to 1.91 for sweet snacks). Some associations between digital food marketing exposure and students' eating behaviors were found; however, print/transport/school food marketing was only related to sweet snack consumption. These study results suggest that cumulative exposure to television food advertising and other food marketing sources are positively linked to adolescents' food choices and eating behaviors. Policy changes to restrict food marketing to young people should include both television and non-broadcast media.
\end{abstract}

\section{Highlights}

- Adolescents are routinely exposed to food marketing via multiple channels.

- Increased exposure associated with adolescents' food choices and eating behaviors.

- Tighter restrictions on food marketing are required across all types of media.

\section{INTRODUCTION}

Food marketing has been identified as an important target for intervention in the prevention of childhood overweight and obesity (World Health Organization, 2006). There is strong and consistent evidence from systematic reviews that food marketing influences children's food preferences, purchases and consumption (Cairns et al., 2009, Institute of Medicine, 2006 and Livingstone and Helsper, 2004). Globally, there is a nutritional imbalance in the types of foods that are promoted to children. A recent study comparing television food advertising patterns in 13 countries across five continents found that the majority of advertised foods were non-core foods that are energy-dense and nutrient-poor (EDNP), and that the rate of EDNP food advertising was higher during children's peak viewing times (Kelly et al., 2010). Television viewing has been shown to be positively associated with 
children's energy intake and consumption of foods most frequently advertised (Utter et al., 2006 and Wiecha et al., 2006).

Exposure to food marketing extends beyond broadcast media with food companies increasingly using integrated marketing campaigns to reach young people through multiple channels that complement and reinforce their promotional messages (Cairns et al., 2009). For example, a UK study found that almost half of food advertisements in magazines for children and adolescents directed readers to a related food marketing website (Cowburn \& Boxer, 2007). Research indicates that young people are exposed to considerable levels of unhealthy food advertising through the Internet (Alvy and Calvert, 2008 and Kelly et al., 2008a), magazines (Cowburn and Boxer, 2007 and Kelly and Chapman, 2007), product packaging (Hebden, King, Kelly, Chapman, \& Innes-Hughes, 2011), in school (Molnar, Garcia, Boninger, \& Merrill, 2008), and via signage around schools (Kelly, Cretikos, Rogers, \& King, 2008b). Digital marketing is a growth area for food marketing, with adolescents a primary target due to their enthusiasm for new media platforms, such as social networks and mobile (smart) phones, as well as their increased spending power (Montgomery \& Chester, 2009).

In Australia, there is limited government statutory regulation of food marketing to young people. Specifically, the Children's Television Standards apply only to designated “children's viewing periods" on free-to-air television (Australian Communications and Media Authority (ACMA), 2009), and thus do not place restrictions on food advertising during times when most children are likely to be watching television (i.e. $6 \mathrm{pm}-9 \mathrm{pm}$ ) (ACMA, 2007). While there are a number of industry self-regulatory codes that deal with food advertising to children, they are voluntary and do not cover all forms of media and promotional strategies (e.g. in-school marketing, digital marketing) (Hebden et al., 2010 and MacKay et al., 2011). Further, these codes do not take into account food advertising targeting adolescents or families (MacKay et al., 2011).

To date, much research has explored the effects of food marketing on children, with a lack of evidence available regarding the influence of marketing on adolescents' food choices and consumption (Institute of Medicine, 2006). Understanding how food marketing may affect adolescents is important given they are at an age where they are beginning to have their own disposable income (from a part-time job or pocket money) and make independent purchase decisions. Few studies have also extended their focus beyond television food advertising to include other marketing sources such as school and the Internet (Story \& French, 2004), even though these are a potentially potent source of influence.

The aim of the present study is to examine associations between various types of food marketing exposure and adolescents' food choices and their fast food, sugary drink and sweet and salty snack food consumption. These food categories were chosen as they are among the most frequently advertised EDNP foods on Australian television (Kelly, Smith, King, Flood, \& Bauman, 2007). We hypothesized that adolescents with greater exposure to each source of food marketing would be more likely to: (i) have tried a new food or drink product they had seen advertised; (ii) have asked their parents/carers to buy a food or drink product they had seen advertised; and (iii) report eating higher amounts of EDNP foods such as fast food, sugary drinks, sweet snacks and salty snacks. 


\section{METHOD}

\subsection{Design and procedure}

In 2009-10, the National Secondary Students' Diet and Activity (NaSSDA) survey was conducted in Australia with a nationally representative sample of students from year levels 8 to 11 (ages $12-17$ years). The sampling procedure was a stratified two-stage probability design, with schools randomly selected at the first stage of sampling and classes selected within schools at the second stage. Within each Australian State and Territory, schools were stratified by the three education sectors (government, Catholic and independent) and randomly selected from each sector to ensure the distribution of schools by sector within each State or Territory was reflected in the sample. Data on students' eating, physical activity and sedentary behaviors were collected via a web-based questionnaire, and anthropometric measurements of students' height, weight and waist circumference were taken by trained researchers in a confidential setting. Active parental consent was required for students to participate in each component of the study. Approval to conduct the study was obtained from the Human Research Ethics Committee of the Cancer Council Victoria, all appropriate education bodies in each State and Territory, and school principals.

\section{$2.2 \quad$ Measures}

\subsubsection{Food marketing exposure}

Students' food marketing exposure was assessed via three separate measures. These measures were developed specifically for this study in the absence of appropriate and relevant existing measures, and were successfully piloted on a sample of over 300 students. First, students were asked to indicate how long they spent watching commercial television on a typical school day, Saturday and Sunday. A weighted average daily time spent watching commercial television was calculated and collapsed into the following categories: none; $2 \mathrm{~h}$ or less per day (moderate viewers); more than $2 \mathrm{~h}$ per day (high viewers).

Second, students indicated whether they had seen a special offer, competition or giveaway for a food or drink product (i) in a magazine, (ii) on public transport or (iii) at school in the last month. Students were coded from 0 to 3 based on their number of print/transport/school marketing sources of exposure.

Third, exposure to digital forms of food marketing was assessed by asking students to indicate whether they had received (i) an email or (ii) a text message (SMS) with a special offer, competition or giveaway related to a food or drink product during the last month. Students were coded from 0 to 2 based on their number of digital marketing sources of exposures.

\subsubsection{Food choices}

Students indicated whether they had (i) tried or (ii) asked their parents/carers to buy a new food or drink product they had seen advertised in the last month.

\subsubsection{Eating behaviors}

Items from a short dietary questionnaire developed by the NSW Centre for Public Health Nutrition were used to measure students' eating behavior (Flood, Webb, \& Rangan, 2005). Fast food consumption was assessed by asking "How often do you have meals or snacks such as burgers, pizza, chicken or chips from places like McDonalds, Hungry Jacks/Burger King, Pizza Hut, KFC, Red Rooster or local take away food places?". Response options ranged from "never" to " 2 or more times a day", and were dichotomized as follows: less than once a week $(=0)$ and 1-2 times or more a week $(=1)$. 
Consumption of sugary drinks was assessed by asking "How much soft drink (like Coke, lemonade), cordials or sports drinks (like Gatorade) do you usually drink? Do not include diet soft drinks." Response options ranged from "I don't drink soft drinks, cordials or sports drinks" to " 5 cups or more a day", and were dichotomized as follows: $1-3$ cups or less a week $(=0)$ and 4-6 cups or more a week $(=1)$.

Two items were used to measure consumption of sweet snacks: "How often do you eat (i) confectionery (such as lollies and chocolates) and (ii) sweet foods, such as sweet biscuits, cakes or muffins?". Responses were dichotomized to identify those students who reported eating both confectionery and sweet foods at least 3-4 times a week. Consumption of salty snacks was assessed by asking "How often do you eat potato crisps/chips or other salty snacks (such as Twisties, corn chips)?", with responses dichotomized as follows: 1-2 times or less a week $(=0)$ and 3-4 times or more a week $(=1)$. It was not possible to further categorize these eating behaviors to differentiate between students who reported not consuming each EDNP food and those who indicated light consumption due to small cell sizes.

\subsubsection{Demographics}

All students were asked to report their sex, school year and home postcode. A measure of socio-economic position (SEP) was determined according to the Socio-Economic Indexes for Areas (SEIFA) Index of Relative Socio-Economic Disadvantage as described by the Australian Bureau of Statistics (2008), based on students' home postcode. Using the national deciles to create quintiles, students were categorized into the following SEP groups: low SEP (1st and 2nd quintiles), medium SEP (3rd and 4th quintiles), and high SEP (5th quintile). Postcode of residence was also used to classify the geographic location of students as either metropolitan or rural/regional. Height and weight measurements were used to calculate students' body mass index (BMI), which was classified into weight categories according to international standard cut-offs developed for children and adolescents (Cole, Bellizzi, Flegal, \& Dietz, 2000).

\subsection{Data analyses}

Data were weighted by state, education sector, school year and sex to ensure the sample obtained reflected the population distribution (Australian Bureau of Statistics, 2010). Analyses were undertaken using Stata SE 11.1 (StataCorp, Texas). Descriptive statistics were used to characterize the sample. Separate logistic regression analyses examined the associations between students' level of exposure to various forms of food marketing and their food choices and eating behaviors. All models controlled for sex, school year, BMI category, SEP and geographic location and adjusted for school level clustering. As preliminary analyses indicated that associations were similar when overweight and obese students were treated both separately and together, for simplicity, these two groups were combined when controlling for BMI category in the final analyses. Due to the large sample size, a conservative level of statistical significance $(p<0.01)$ was applied.

\section{RESULTS}

A total of 238 secondary schools were surveyed nationally (school response rate $=39 \%$ ), with data collected from 14,066 students in year levels 8 to 11 (student response rate $=54 \%$ ). The most common reasons for school non-participation were time demands and commitments to other surveys. Students were excluded from the sample if they were aged less than 12 or greater than 17 years on the day of the survey $(n=53)$, had not completed the survey up to a 
specified inclusion point $(n=223)$, or had no physical measurements taken $(n=1515)$. A further 87 students were excluded due to no SEP index value being available for their postcode.

Table 1. Demographic profile of sample $(N=12,188)$.

\begin{tabular}{|c|c|c|}
\hline & $n$ & Percentage \\
\hline \multicolumn{3}{|l|}{ Sex } \\
\hline Male & 6460 & 53.0 \\
\hline Female & 5728 & 47.0 \\
\hline \multicolumn{3}{|l|}{ Year level } \\
\hline 8 & 3772 & 31.0 \\
\hline 9 & 3340 & 27.4 \\
\hline 10 & 2647 & 21.7 \\
\hline 11 & 2429 & 19.9 \\
\hline \multicolumn{3}{|l|}{ BMI category } \\
\hline Healthy weight & 9418 & 77.3 \\
\hline Overweight/obese & 2770 & 22.7 \\
\hline \multicolumn{3}{|l|}{ SEP } \\
\hline Low & 3932 & 32.3 \\
\hline Medium & 5062 & 41.5 \\
\hline High & 3194 & 26.2 \\
\hline \multicolumn{3}{|l|}{ Geographic location } \\
\hline Metropolitan & 7841 & 64.3 \\
\hline Rural & 4347 & 35.7 \\
\hline \multicolumn{3}{|c|}{ Commercial TV viewing } \\
\hline None & 2401 & 19.8 \\
\hline $2 \mathrm{~h}$ or less/day & 7182 & 59.1 \\
\hline More than $2 \mathrm{~h} /$ day & 2567 & 21.1 \\
\hline \multicolumn{3}{|c|}{ Number of print/transport/school marketing sources } \\
\hline 0 & 3695 & 30.3 \\
\hline 1 & 2190 & 18.0 \\
\hline 2 & 2996 & 24.6 \\
\hline 3 & 3307 & 27.1 \\
\hline \multicolumn{3}{|c|}{ Number of digital marketing sources } \\
\hline 0 & 9184 & 75.4 \\
\hline 1 & 1765 & 14.5 \\
\hline 2 & 1239 & 10.2 \\
\hline
\end{tabular}

Based on unweighted data.

Note: Percentages are rounded so may not sum to $100 \%$.

SEP: Socio-economic position.

A summary of the demographic profile of the sample is shown in Table 1. Around one in five students watched more than two hours of commercial television on average per day. Over two-thirds were exposed to at least one source of print, public transport or school food 
marketing in the last month, while one-quarter had received a food marketing-themed email and/or SMS.

Table 2. Associations between food marketing exposure and adolescent food choices and eating behavior: Adjusted odds ratios (OR) and 95\% confidence intervals (Cl). ${ }^{\text {a }}$

\begin{tabular}{|c|c|c|c|c|c|c|c|c|c|c|c|c|}
\hline \multirow{3}{*}{$\begin{array}{l}\text { Food marketing } \\
\text { exposure }\end{array}$} & \multicolumn{4}{|c|}{ Food choices } & \multicolumn{8}{|c|}{ Eating behavior } \\
\hline & \multicolumn{2}{|c|}{$\begin{array}{l}\text { Try product } \\
\text { advertised } \\
\text { ( } \geq \text { once in last } \\
\text { month) } \\
n=11,795\end{array}$} & \multicolumn{2}{|c|}{$\begin{array}{l}\text { Ask for product } \\
\text { advertised } \\
\text { ( } \geq \text { once in last } \\
\text { month) } \\
n=11,795\end{array}$} & \multicolumn{2}{|c|}{$\begin{array}{l}\text { Fast food } \\
(\geq 1- \\
2 \text { times/week) } \\
n=12,035\end{array}$} & \multicolumn{2}{|c|}{$\begin{array}{l}\text { Sugary drinks } \\
(\geq 4- \\
6 \text { cups/week) } \\
n=12,072\end{array}$} & \multicolumn{2}{|c|}{$\begin{array}{l}\text { Sweet snacks }{ }^{c} \\
(\geq 3- \\
4 \text { times/week) } \\
n=12,022\end{array}$} & \multicolumn{2}{|c|}{$\begin{array}{l}\text { Salty snacks }^{d} \\
(\geq 3- \\
4 \text { times/week) } \\
n=12,045\end{array}$} \\
\hline & $\begin{array}{l}\text { Adj. } \\
\text { OR }\end{array}$ & $\begin{array}{l}95 \% \\
\mathrm{Cl}\end{array}$ & $\begin{array}{l}\text { Adj. } \\
\text { OR }\end{array}$ & $\begin{array}{l}95 \% \\
\mathrm{Cl}\end{array}$ & $\begin{array}{l}\text { Adj. } \\
\text { OR }\end{array}$ & $\begin{array}{l}95 \% \\
\mathrm{Cl}\end{array}$ & $\begin{array}{l}\text { Adj. } \\
\text { OR }\end{array}$ & $\begin{array}{l}95 \% \\
\mathrm{Cl}\end{array}$ & $\begin{array}{l}\text { Adj. } \\
\text { OR }\end{array}$ & $\begin{array}{l}95 \% \\
\mathrm{Cl}\end{array}$ & $\begin{array}{l}\text { Adj. } \\
\text { OR }\end{array}$ & $\begin{array}{l}95 \% \\
\mathrm{Cl}\end{array}$ \\
\hline \multicolumn{13}{|c|}{ Commercial TV viewing } \\
\hline None & 1 & & 1 & & 1 & & 1 & & 1 & & 1 & \\
\hline $2 \mathrm{~h}$ or less/day & 1.15 & $\begin{array}{l}1.01- \\
1.31\end{array}$ & $1.25^{*}$ & $\begin{array}{l}1.10- \\
1.42\end{array}$ & 0.93 & $\begin{array}{l}0.81- \\
1.06\end{array}$ & 0.99 & $\begin{array}{l}0.84- \\
1.16\end{array}$ & 1.18 & $\begin{array}{l}1.02- \\
1.36\end{array}$ & 1.07 & $\begin{array}{l}0.91- \\
1.25\end{array}$ \\
\hline $\begin{array}{l}\text { More than } \\
2 \mathrm{~h} / \text { day }\end{array}$ & $1.48^{* *}$ & $\begin{array}{l}1.27- \\
1.71\end{array}$ & $1.61^{* *}$ & $\begin{array}{l}1.38- \\
1.88\end{array}$ & $1.31^{*}$ & $\begin{array}{l}1.10- \\
1.57\end{array}$ & $1.73^{* *}$ & $\begin{array}{l}1.43- \\
2.09\end{array}$ & $1.91^{* *}$ & $\begin{array}{l}1.60- \\
2.27\end{array}$ & $1.84^{* *}$ & $\begin{array}{l}1.59- \\
2.12\end{array}$ \\
\hline \multicolumn{13}{|c|}{ Number of print/transport/school marketing sources } \\
\hline 0 & 1 & & 1 & & 1 & & 1 & & 1 & & 1 & \\
\hline 1 & $1.82^{* *}$ & $\begin{array}{l}1.58- \\
2.09\end{array}$ & $1.47^{* *}$ & $\begin{array}{l}1.27- \\
1.71\end{array}$ & 0.88 & $\begin{array}{l}0.76- \\
1.02\end{array}$ & 0.83 & $\begin{array}{l}0.71- \\
0.98\end{array}$ & 1.09 & $\begin{array}{l}0.92- \\
1.29\end{array}$ & 1.03 & $\begin{array}{l}0.88- \\
1.21\end{array}$ \\
\hline 2 & $2.48^{* *}$ & $\begin{array}{l}2.17- \\
2.82\end{array}$ & $2.27^{* *}$ & $\begin{array}{l}1.95- \\
2.64\end{array}$ & 0.95 & $\begin{array}{l}0.83- \\
1.09\end{array}$ & 1.02 & $\begin{array}{l}0.88- \\
1.18\end{array}$ & 1.33 & $\begin{array}{l}1.10- \\
1.62\end{array}$ & 1.03 & $\begin{array}{l}0.87- \\
1.20\end{array}$ \\
\hline 3 & $3.74^{* *}$ & $\begin{array}{l}3.23- \\
4.34\end{array}$ & $3.53^{* *}$ & $\begin{array}{l}2.98- \\
4.19\end{array}$ & 1.03 & $\begin{array}{l}0.90- \\
1.18\end{array}$ & 1.03 & $\begin{array}{l}0.89- \\
1.19\end{array}$ & 1.54 & $\begin{array}{l}1.31- \\
1.82\end{array}$ & 1.09 & $\begin{array}{l}0.94- \\
1.26\end{array}$ \\
\hline \multicolumn{13}{|c|}{ Number of digital marketing sources } \\
\hline 0 & 1 & & 1 & & 1 & & 1 & & 1 & & 1 & \\
\hline 1 & $1.47^{* *}$ & $\begin{array}{l}1.28- \\
1.70\end{array}$ & $1.34^{* *}$ & $\begin{array}{l}1.17- \\
1.54\end{array}$ & 1.24 & $\begin{array}{l}1.08- \\
1.41\end{array}$ & 1.15 & $\begin{array}{l}0.99- \\
1.34\end{array}$ & 1.06 & $\begin{array}{l}0.89- \\
1.25\end{array}$ & 1.06 & $\begin{array}{l}0.92- \\
1.21\end{array}$ \\
\hline 2 & $2.54^{* *}$ & $\begin{array}{l}2.03- \\
3.18\end{array}$ & $3.19^{* *}$ & $\begin{array}{l}2.62- \\
3.89\end{array}$ & $2.25^{* *}$ & $\begin{array}{l}1.89- \\
2.67\end{array}$ & $1.34^{*}$ & $\begin{array}{l}1.13- \\
1.58\end{array}$ & 1.19 & $\begin{array}{l}1.00- \\
1.43\end{array}$ & $1.26^{*}$ & $\begin{array}{l}1.06- \\
1.50\end{array}$ \\
\hline
\end{tabular}

${ }^{*} p<0.01 ;{ }^{* *} p<0.001$.

${ }^{a}$ Adjusted for sex, school year, BMI category, SEP, geographic location and all other food marketing exposure variables in the model, as well as school clustering.

${ }^{b}$ Includes soft drink, cordials and sports drinks (non-diet varieties). Cordials are non-alcoholic concentrated syrups that are usually fruit-flavored and are mixed with water before drinking.

${ }^{c}$ Includes confectionery (e.g. candy, chocolate) and other sweet foods (e.g. cookies, cakes, muffins).

${ }^{\mathrm{d}}$ Includes potato crisps/chips and other salty snacks (e.g. cheese-flavored snacks, corn chips).

\subsection{Food choices}

As presented in Table 2, compared to students who watched no commercial television, moderate viewers were more likely to report asking for a product they had seen advertised at least once in the last month. The highest viewers were more likely to have both asked for a product and tried a new product they had seen advertised at least once in the last month. Exposure to print/transport/school food marketing and digital food marketing was strongly 
associated with students' food choices. As students' level of exposure to all forms of marketing increased, so too did the likelihood they had tried a new product or asked for a product they had seen advertised in the last month.

\subsection{Eating behavior}

Students who watched more than two hours of commercial television per day reported higher consumption of fast food, sugary drinks, sweet and salty snacks compared to students who watched no commercial television (see Table 2). Print/transport/school food marketing was largely unrelated to students' eating behaviors, with the only significant differences being that students exposed to two or three of these marketing sources reported higher consumption of sweet snacks than those with no exposure.

Some associations between digital food marketing exposure and students' eating behavior were found. Compared to students with no exposure to digital marketing in the last month, students who were exposed to one or two sources were more likely to have reported higher consumption of fast food, while students who were exposed to two sources reported higher consumption of sugary drinks and salty snacks.

\section{DISCUSSION}

The results indicate that adolescents are routinely exposed to food marketing, in particular via commercial television and ambient media, and that cumulative exposure to food marketing is linked to their food choices and eating behaviors. As hypothesized, commercial television viewing as well as print/transport/school and digital food marketing were all positively associated with students having recently tried a new product they had seen advertised or having made a purchase request for an advertised product. We also observed a significant positive relationship between greater exposure to commercial television viewing and digital food marketing and reported consumption of EDNP foods. Increased exposure to food advertising via print/transport/school sources was related only to higher reported intake of sweet snacks.

While prior studies have demonstrated a positive link between television viewing and adolescents' consumption of commonly advertised EDNP foods (Utter et al., 2006 and Wiecha et al., 2006), our study builds on that research by using a more specific measure of commercial television advertising exposure. Our finding of a possible doseresponse relationship is consistent with results from studies examining the impact of advertising exposure on adolescent alcohol use (Anderson, de Bruijn, Angus, Gordon, \& Hastings, 2009) and smoking prevalence (MacFadyen, Hastings, \& MacKintosh, 2001), and highlights the need for tighter restrictions on the advertising of EDNP foods. Importantly, all types of food marketing exposure were independently associated with students' food choices and eating behaviors. Thus, with the shift towards more integrated marketing campaigns, it is important that any policy changes encompass the multiple media used by food companies to advertise their products to young people.

The pattern of results observed for print/transport/school food marketing in our study could possibly reflect the different marketing strategies of food companies. For example, there was a higher number of food references for chocolate and confectionery in Australian children's magazines than for fast food, sugary drinks and snack foods such as potato crisps (Kelly \& Chapman, 2007). Although students' level of exposure to digital food marketing was much 
lower than other channels, the associations found for this type of advertising exposure were generally strong. One explanation is that digital marketing is more personalized and facilitates active engagement compared to television or ambient forms of marketing that are more passive (Montgomery \& Chester, 2009). For example, digital marketing prompts the recipient to make a conscious choice about opening a personal email and/or SMS. Further, consumers often opt-into receive digital marketing (e.g. through entering a competition on packaging or joining a website to access interactive games), which may render it more influential.

A number of study limitations should be noted. First, due to the cross-sectional design of the study, we are unable to make causal inferences about the relations between food marketing exposure and students' food choices and eating behaviors. Further research including cohort and intervention studies is needed to determine causality. Second, the exposure measures used (excepting commercial television viewing) were limited in that they focused exclusively on special offers, competitions and giveaways and did not capture all non-broadcast food advertising channels such as sport sponsorship (Sherriff, Griffiths, \& Daube, 2010) and interactive online games (Lee, Choi, Quilliam, \& Cole, 2009). However, as there is a lack of validated survey questions available to assess adolescent exposure to food marketing, this study contributes to the literature by attempting to quantify levels of exposure in a large national sample. For future research, it would be beneficial to include other potentially important sources of marketing exposure for adolescents such as websites and at the point-ofsale, and to broaden the scope of the measures to take into account advertising that may be simply "reminding" consumers about a particular product.

A third limitation of our study was that the data were self-reported and relied on students to recall and correctly record their behaviors as well as recognize and remember specific types of marketing efforts. Thus, our data may have been affected by social desirability bias or measurement error. For example, research indicates that young people tend to underestimate their intake of EDNP foods such as takeaway meals and soft drinks when responding to short dietary questions (Gwynn et al., 2010). We would expect, though, that the likely underestimation of these behaviors and students' level of exposure to food marketing would have weakened rather than strengthened the observed associations.

With the effects of food advertising on adolescents less established than for children, the findings from this study make an important contribution to the research area. To our knowledge, it is the first study to indicate that exposure to food marketing via television and non-broadcast sources are independently associated with adolescents' food choices and eating behavior, and to show evidence of a dose-response relationship. While adolescents' eating patterns are complex and determined by multiple factors (e.g. parents, peers, taste, price, convenience) (Story, Neumark-Sztainer, \& French, 2002), efforts to reduce time spent watching commercial television as well as restricting the amount of food advertising across all types of media are likely to represent positive steps towards improving the diets of young people.

\section{ACKNOWLEDGEMENT}

The National Secondary Students' Diet and Activity Survey was jointly funded by state Cancer Councils through Cancer Council Australia, and by the National Heart Foundation of Australia. I-view was responsible for fieldwork coordination. We would like to thank the school principals, teachers and students who participated in this study. 


\section{REFERENCES}

Alvy and Calvert, 2008

L.M. Alvy, S.L. Calvert

Food marketing on popular children's web-sites. A content analysis

Journal of the American Dietetic Association, 108 (2008), pp. 710-713

Anderson et al., 2009

P. Anderson, A. de Bruijn, K. Angus, R. Gordon, G. Hastings

Impact of alcohol advertising and media exposure on adolescent alcohol use. A systematic review of longitudinal studies

Alcohol and Alcoholism, 44 (2009), pp. 229-243

Australian Bureau of Statistics, 2008

Australian Bureau of Statistics (2008). Information paper. An introduction to SocioEconomic Indexes for Areas (SEIFA) 2006. Catalogue no. 2039.0. Canberra: Australian Bureau of Statistics.

Australian Bureau of Statistics, 2010

Australian Bureau of Statistics (2010). Schools Australia, 2009. Catalogue no. 4221.0. Canberra: Australian Bureau of Statistics.

Australian Communications and Media Authority, 2007

Australian Communications and Media Authority (2007). Children's viewing patterns on commercial, free-to-air and subscription television. Canberra: Australian Communications and Media Authority. $<$ http://www.acma.gov.au.ezproxy.uow.edu.au/webwr/_assets/main/lib310132/children_view ing_patterns_commercial_free-to-air_subscription_television.pdf $>$ Retrieved 05.09.11.

Australian Communications and Media Authority, 2009

Australian Communications and Media Authority (2009). Children's television's standards 2009. Canberra: Australian Communications and Media Authority. $<$ http://www.acma.gov.au.ezproxy.uow.edu.au/webwr/aba/contentreg/codes/television/docu ments/childrens_tv_standards_2009.pdf $>$ Retrieved 05.09.11.

Cairns et al., 2009

Cairns, G., Angus, K., \& Hastings, G. (2009). The extent, nature and effects of food promotion to children. A review of the evidence to December 2008. World Health Organization.

$<$ http://www.who.int.ezproxy.uow.edu.au/dietphysicalactivity/Evidence_Update_2009.pdf $>$ Retrieved 04.04.11.

Cole et al., 2000

T.J. Cole, M.C. Bellizzi, K.M. Flegal, W.H. Dietz 
Establishing a standard definition for child overweight and obesity worldwide. International survey

BMJ, 320 (2000), pp. 1240-1243

Cowburn and Boxer, 2007

G. Cowburn, A. Boxer

Magazines for children and young people and the links to Internet food marketing. A review of the extent and type of food advertising

Public Health Nutrition, 10 (2007), pp. 1024-1031

Flood et al., 2005

Flood, V., Webb, K., \& Rangan, A. (2005). Recommendations for short questions to assess food consumption in children for the NSW Health surveys. NSW Centre for Public Health Nutrition.

$<$ http://www.health.nsw.gov.au.ezproxy.uow.edu.au/pubs/2006/pdf/npa_foodconsumption_150.pdf $>$ Retrieved 15.09.10.

Gwynn et al., 2010

Gwynn, J. D., Flood, V. M., D’Este, C. A., Attia, J. R., Turner, N., Cochrane, J., et al. (2010). The reliability and validity of a short FFQ among Australian Aboriginal and Torres Strait Islander and non-Indigenous rural children. Public Health Nutrition. doi: $10.1017 /$ S 1368980010001928.

Hebden et al., 2010

L. Hebden, L. King, B. Kelly, K. Chapman, C. Innes-Hughes

Industry self-regulation of food marketing to children. Reading the fine print

Health Promotion Journal of Australia, 21 (2010), pp. 229-235

Hebden et al., 2011

L. Hebden, L. King, B. Kelly, K. Chapman, C. Innes-Hughes

A menagerie of promotional characters. Promotion of energy-dense, nutrient-poor foods to children on food packaging

Journal of Nutrition Education Behavior, 43 (2011), pp. 349-355

Institute of Medicine, 2006

Institute of Medicine

Food marketing to children and youth. Threat or opportunity?

The National Academies Press, Washington, DC (2006)

Kelly et al., 2008a

B. Kelly, K. Bochynska, K. Kornman, K. Chapman

Internet food marketing on popular children's websites and food product websites in Australia

Public Health Nutrition, 11 (2008), pp. 1180-1187

Kelly and Chapman, 2007

B. Kelly, K. Chapman

Food references and marketing to children in Australian magazines. A content analysis

Health Promotion International, 22 (2007), pp. 284-291 
Kelly et al., 2008b

B. Kelly, M. Cretikos, K. Rogers, L. King

The commercial food landscape. Outdoor food advertising around primary schools in Australia

Australian and New Zealand Journal of Public Health, 32 (2008), pp. 522-528

Kelly et al., 2010

B. Kelly, J.C.G. Halford, E.J. Boyland, K. Chapman, I. Bautista-Castaño, C. Berg et al. Television food advertising to children. A global perspective

American Journal of Public Health, 100 (2010), pp. 1730-1736

Kelly et al., 2007

B. Kelly, B. Smith, L. King, V. Flood, A. Bauman

Television food advertising to children. The extent and nature of exposure

Public Health Nutrition, 10 (2007), pp. 1234-1240

Lee et al., 2009

M. Lee, Y. Choi, E.T. Quilliam, R.T. Cole

Playing with food. Content analysis of food advergames

Journal of Consumer Affairs, 43 (2009), pp. 129-154

Livingstone and Helsper, 2004

S. Livingstone, E. Helsper

Advertising foods to children. Understanding promotion in the context of children's daily lives

Department of Media and Communications, London School of Economics and Political Science, London, UK (2004)

MacFadyen et al., 2001

L. MacFadyen, G. Hastings, A.M. MacKintosh

Cross sectional study of young people's awareness of and involvement with tobacco marketing

BMJ, 322 (2001), pp. 513-517

MacKay et al., 2011

S. MacKay, N. Antonopoulos, J. Martin, B.A. Swinburn

A comprehensive approach to protecting children from unhealthy food advertising

Obesity Policy Coalition, Melbourne (2011)

Molnar et al., 2008

A. Molnar, D.R. Garcia, F. Boninger, B. Merrill

Marketing of foods of minimal nutritional value to children in schools

Preventive Medicine, 47 (2008), pp. 504-507

Montgomery and Chester, 2009

K.C. Montgomery, J. Chester

Interactive food and beverage marketing. Targeting adolescents in the digital age

Journal of Adolescent Health, 45 (Suppl. 3) (2009), pp. S18-S29 
Sherriff et al., 2010

J. Sherriff, D. Griffiths, M. Daube

Cricket. Notching up runs for food and alcohol companies?

Australian and New Zealand Journal of Public Health, 34 (2010), pp. 19-23

Story and French, 2004

M. Story, S. French

Food advertising and marketing directed at children and adolescents in the US

International Journal of Behavioral Nutrition and Physical Activity, 1 (2004), p. 3

Story et al., 2002

M. Story, D. Neumark-Sztainer, S. French

Individual and environmental influences on adolescent eating behaviours

Journal of the American Dietetic Association, 102 (Suppl. 3) (2002), pp. S40-S51

Utter et al., 2006

J. Utter, R. Scragg, D. Schaaf

Associations between television viewing and consumption of commonly advertised foods among New Zealand children and young adolescents

Public Health Nutrition, 9 (2006), pp. 606-612

Wiecha et al., 2006

J.L. Wiecha, K.E. Peterson, D.S. Ludwig, J. Kim, A. Sobol, S.L. Gortmaker

When children eat what they watch. Impact of television viewing on dietary intake in youth

Archives of Pediatrics and Adolescent Medicine, 160 (2006), pp. 436-442

World Health Organization, 2006

World Health Organization (2006). Marketing of food and non-alcoholic beverages to children. Report of WHO forum and technical meeting. Oslo: World Health Organization. $<$ http://www.who.int.ezproxy.uow.edu.au/dietphysicalactivity/publications/Oslo\%20meeting \%20layout\%2027\%20NOVEMBER.pdf> Retrieved 30.06.11. 